\title{
The Impact Of Working Capital Turnover, Inventory Turnover, Cash Turnover, And Company Size On Profitability.
}

\author{
Vernanda Claudia ${ }^{1}$, Herlina Lusmeida ${ }^{2}$ \\ \{Herlina.Lusmeida@uph.edu ${ }^{1}$,Herlina.Lusmeida@uph.edu ${ }^{2}$ \} \\ Alumni of University of Pelita Harapan ${ }^{1}$, University of Pelita Harapan ${ }^{2}$
}

\begin{abstract}
The purpose of this research is to examine the effect of working capital management on profitability. The variables used in this research are divided into dependent and independent variables. The dependent variable is profitability and the independent variables are working capital turnover, cash turnover, inventory turnover, and company size. This research was conducted at manufacturing companies listed on Indonesia Stock Exchange period 2013-2016 which amounted to 376 samples during 4 years. The determination of the number of samples in this study using purposive sampling method and data analysis technique used is multiple linear regression and samples tested using T-Test and F-Test. The results of this research showed that the variables of inventory turnover and company's size have a positive effect and significant to profitability, while working capital turnover and cash turnover have negative influence to profitability.
\end{abstract}

Keywords: Profitability, Working Capital, Company Size, Profitability

\section{Introduction}

Every company will do various activities to achieve the intended purpose. Any activity implemented by companies always need funds, both to finance operational activities day-today as well as to finance its long-term investments. The funds used to carry out daily operational activities called working capital. Working capital is required by every company to finance the activities its day-to-day operations, where the working capital it has spent is expected will be able to re-enter the company in a short time through the sale of its production. Working capital from sales of the product will be issued immediately to finance the next operation. This working capital will continue to spin for each period in the company (Riyanto, 2015).

The working capital management used in this research is cash turnover, receivable turnover, and inventory turnover. Cash turnover is used to measure the level of cash availability to pay bills (debt) and costs related to sales (Kasmir, 2012). Cash has the highest level of liquidity in the working capital element. Where the company's cash is higher then the level of liquidity also high and reduce the risk of the company otherwise if cash is smaller companies are threatened can not meet the financial obligations of the company (Riyanto, 2011). The higher the cash flow rate means the faster the return of cash into the company. Thus cash will be able reused to finance operational activities so it will not to disrupting the company's financial condition (Wild et al., 2005). 


\section{Literature review}

\subsection{Working capital}

Working capital is the capital used to finance the operations of everyday companies, especially those with short durations. If the company lacks working capital to expand its sales and increase its production, then it is likely to lose revenue and profits. Companies that do not have sufficient working capital, cannot pay their obligations on time and will face financial problems. According to Riyanto (2011), working capital investment is an ongoing process as long as the company operates. Each working capital element must be managed to be in the optimal state.

\subsection{Profitability}

Profitability is the ability of the company in obtaining profit or profit (Rahajaputra, 2009), where the relationship in sales, total assets or own capital. While according to, Wiagustini (2010), profitability shows the company's ability to measure the effectiveness of the company's working capital management. The ability to earn profits can be measured from the capital itself as well as from all funds invested.

\subsection{Inventory}

The largest investment in current assets for most industrial firms is inventory. It is said that the investment is due to the bonded capital in the stock so that it cannot be used for other purposes. Inventory turnover determines the amount of capital tied up therein. The faster the inventory turnaround means the smaller the capital to invest in inventory. Inventories can be classified into four, namely: Supplies, raw materials, in-process goods, and finished goods (Husnan, 2008). The amount of the value of inventory is determined by the policy of inventory management and production process of the company. Inventories are required to enable the company to fulfill customer orders within a short time and also to maintain the smooth operation of the company's business. If the company keeps a large amount of inventory, it means that the company will bear its storage costs. If the company keeps a small amount of inventory, it means that the company will incur a recurring booking fee. Mistakes determining the amount of investment in inventory will reduce the company's profit. In terms of the balance sheet, the inventory will be in the form of goods or materials remaining, or items ready for sale in the normal period of the company

\subsection{Liquidity}

Liquidity refers to a company's ability to pay its bills from cash or from assets that can be turned into cash very quickly. Munawir (2004) stated Liquidity is showing the ability of a company to meet its financial obligations that must be met immediately, or the company's ability to meet financial obligations when billed. Syamsuddin (2000) Liquidity is an indicator of the company's ability to pay all short-term financial liabilities at maturity by using current assets available. 


\subsection{Company size}

Size measurement / size enterprise (company size) indicates the size of the size of the company. To obtain measurements easy and taking into account the availability of the data, the research firm size is proxied by total assets given the symbol with ASSET. Total assets are the sum of current assets and fixed assets owned by the company for one year (Kusuma, 2005).

\subsection{Conceptual framework}

Systematically the framework of thought in this study can be seen on Figure 1 below:

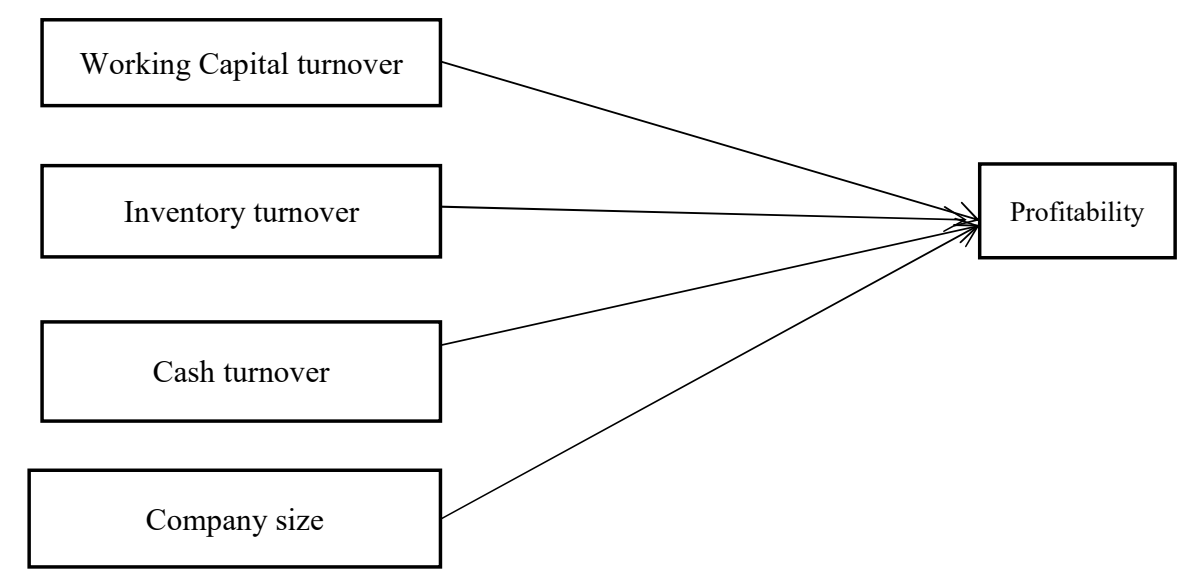

Fig.1. Conceptual Framework

\subsection{Hypothesis development}

Based on literature review and conceptual framework. The hypothesis for this study:

$\mathrm{H}_{1}=$ Work capital turnover has a positive effect to profitability (ROI).

$\mathrm{H}_{2}=$ Inventory turnover has a positive effect on profitability (ROI).

$\mathrm{H}_{3}=$ Cash turnover has a positive effect on Profitability (ROI).

$\mathrm{H}_{4}=$ Company size has a positive effect to profitability (ROI)

Population of this research is all manufacturing companies listed in IDX along the year 2013-2016 (four years). By using purposive sampling method, sample selection is performed with the criteria.

The data collection method adopted in this study is the quantitative collection method. The regression model that is used in this study to test all the hypotheses comprised of four independent variables and one dependent variable. Profitability is the dependent variable and the independent variables are: Working Capital Turnover, Inventory Turnover, Cash Turnover, and Company Size. Furthermore, on the basis of review of the literature; following relationships have been predicted to be further tested statistically to conclude the results of the study.

$$
\mathrm{PROF}=\alpha+\beta_{1} \mathrm{WC}+\beta_{2} \mathrm{IT}+\beta_{3} \mathrm{CT}+\beta_{4} \mathrm{ASSET}+\varepsilon
$$

Which,

$$
\begin{array}{ll}
\alpha & =\text { Constant term } \\
\beta & =\text { Coefficient term } \\
\text { PROF } & =\text { Profitability }
\end{array}
$$




$$
\begin{array}{ll}
\text { WC } & =\text { Working capital } \\
\text { IT } & =\text { Inventory turnover } \\
\text { CT } & =\text { Cash turnover } \\
\text { ASSET } & =\text { Company size } \\
\varepsilon & =\text { error term }
\end{array}
$$

\section{Result and discussion}

\subsection{Result}

\subsubsection{Descriptive statistics}

The descriptive statistics of the samples consist of the minimum which is the lowest value of the variable, maximum which is the highest value of the variable, mean which is the average value of the variable, and standard deviation which is the spread of data of each of the variables in the sample which is presented in table 1 as follows:

Table 1. Descriptive Statistics

\begin{tabular}{lrrrrrr}
\hline & N & Minimum & Maximum & Mean & Std. Deviation \\
Statistic & \multicolumn{1}{c}{ Statistic } & \multicolumn{1}{c}{ Statistic } & \multicolumn{1}{c}{ Statistic } & \multicolumn{1}{c}{ Statistic } & \multicolumn{1}{c}{ Statistic } \\
\hline ROI & 376 & -.22 & .31 & .0065 & .04655 & .002 \\
WC & 376 & -223.69 & 1893.95 & 15.1517 & 155.24669 & 24101.536 \\
IT & 376 & .00 & 51.18 & .8268 & 3.60840 & 13.021 \\
CT & 376 & .00 & 526.45 & 14.4157 & 63.32512 & 4010.071 \\
ASSET & 376 & .00 & 10.45 & 1.4432 & 3.29177 & 10.836 \\
Valid N (listwise) & 376 & & & & & \\
\hline
\end{tabular}

From the table above, ROI, which is the dependent variable, has a minimum value of -0.22 and a maximum value of 0.31 . It also has a mean of 0.0065 which means that the average ROI of the sample data is around $0.6 \%$. The standard deviation for ROI is 0.04655 which means that the variance and spread of the data is small.

WC (Working Capital Turnover) has a minimum value of -223.69 and a maximum value of 1893.95. The mean is 15.1517 with standard deviation of 155.24669. IT (Inventory Turnover) has a minimum value of 0.00 and maximum value of 51.18 , while the mean is $82 \%$ with standard deviation of 3.60840. CT (Cash Turnover) has minimum value of 0.00 and maximum value of 526.45 with mean of 14.4157 and standard deviation of 63.32512. Lastly, ASSET (Company Size) has minimum value of 0.00 and maximum value of 10.45, the mean is 1.4432 and standard deviation is 3.29177 .

\subsubsection{Prelimenary test}

To get Best Linear Unbiased Estimator (BLUE), researcher runs some preliminary tests (classical assumption test) such as normality test, multicollinearity test, autocorrelation test, and heteroscedasticity test. Based on the classic assumption test conducted in this study, it can be seen that the data in this study passed the classical assumption test, this means that the data tested in this study is normal, avoiding the problem of heteroscedasticity, multicollinearity and autocorrelation, so that it can proceed to the next test namely hypothesis testing. 


\subsubsection{Hypothesis test}

\section{a. F test}

In the table below there is a sig column which is the significance value of a double effect between variable, containing 0,000 which means its significance level is 0.000 . Determine the rules of decision-making are as follows:

If $0.05<\mathrm{sig}$, then the simultaneous effect is not significant.

If $0.05>\mathrm{sig}$, then the double effect is significant.

So, based on the calculation of SPSS, obtained the result that sig study $0,000<0,05$, so it shows and been tested and accepted that $\mathrm{X}_{1}, \mathrm{X}_{2}, \mathrm{X}_{3}, \mathrm{X}_{4}$ have significant influence to ROI.

Table 2. ANOVA ${ }^{\text {a }}$ test

\begin{tabular}{|c|c|c|c|c|c|c|}
\hline Model & & Sum of Squares & $\mathrm{df}$ & Mean Square & $\mathrm{F}$ & Sig. \\
\hline \multirow{3}{*}{1} & Regression & .235 & & $4 \quad .059$ & 8.911 & $.000^{\mathrm{b}}$ \\
\hline & Residual & 2.449 & & .007 & & \\
\hline & Total & 2.684 & & 375 & & \\
\hline
\end{tabular}

a. Dependent Variable: ROI

b. Predictors: (Constant), ASSET, IT, WC, CT

\section{b. $\mathbf{T}$ test}

This test is conducted to test the significance of the coefficient of each independent variable partially to the dependent variable.

Based on table 3 below it is known that the sig value for the $\mathrm{WC}$ variable is $0.027<0.05$, which means that the WC coefficient has significant effect on ROI.

Based on Table 3, it is known that the value of sig for IT is $0.049<0.05$, which means that the IT coefficient has significant effect on ROI

Based on table 3, it is known that the sig value for the variable CT is $0.002<0.05$, then $\mathrm{Ho}_{3}$ is rejected, which means that the coefficient of CT significantly affect the ROI.

Based on table 3, it is known that the sig value for ASSET variable is $0.000<0,05$, so $\mathrm{Ho}_{4}$ is rejected, which means that ASSET coefficient has significant effect to ROI.

Table 3. The result of $\mathrm{T}$ test

\begin{tabular}{|c|c|c|c|c|c|c|}
\hline \multicolumn{2}{|c|}{$\overline{\text { Model }}$} & \multicolumn{2}{|c|}{$\begin{array}{l}\text { Unstandardized } \\
\text { Coefficients }\end{array}$} & \multirow{2}{*}{$\begin{array}{l}\text { Standardized } \\
\text { Coefficients } \\
\text { Beta }\end{array}$} & \multirow[t]{2}{*}{$\mathrm{t}$} & \multirow[t]{2}{*}{ Sig. } \\
\hline & & B & Std. Error & & & \\
\hline & (Constant) & -.184 & .058 & & -3.175 & .002 \\
\hline & WC & $-6.005 \mathrm{E}-005$ & .000 & -.110 & -2.223 & .027 \\
\hline \multirow[t]{3}{*}{1} & IT & .000 & .001 & .034 & .686 & .049 \\
\hline & $\mathrm{CT}$ & .000 & .000 & -.156 & -3.111 & .002 \\
\hline & ASSET & .026 & .006 & .207 & 4.129 & .000 \\
\hline
\end{tabular}

Based on the sample data that researcher has collected and tested, the result shows that working capital turnover has negative effect on profitability, which is not along with the hypothesis that says that working capital turnover has a positive effect on profitability. However, research on this company shows that a high level of sales will decrease profitability. This is because the company has not used working capital efficiently. 
The result shows that inventory turnover significantly has positive effect on profitability. The existence of a positive influence indicates that the higher inventory turnover rate will increase the profitability of the company. This is because the inventory invested by the company must be precise with the company's needs so that interest costs are reduced, minimize storage and maintenance costs in the warehouse, the company suffering losses, so that all this will increase the volume of sales and profits obtained by the company will also be greater.

The next results shows that cash turnover has negative and significant effect on profitability, this maybe happened because the company's working capital management is not effective enough in managing the use of working capital in the company. The last results shows that company size significantly has positive effect on profitability.

\section{Conclusion}

This study shows the result of negative influence of working capital turnover on profitability, positive influence of inventory turnover on profitability, negative influence of cash turnover on profitability, and positive influence of company size on profitability. In terms of significance, all of the independent variables have significant effect to profitability.

\section{References}

[1] Husnan, S. : Manajemen Keuangan : Teori dan Penerapan Buku 1. Penerbit BPFE, Yogyakarta (2008)

[2] Kasmir.: Analisis Laporan Keuangan: Rajawali Pers, Jakarta (2012)

[3] Kusuma, H. : Faktor-Faktor yang Mempengaruhi Struktur Modal Perusahaan Go Public di BEJ. Sinerg, Jakarta (2005)

[4] Munawir, S. : Analisa Laporan Keuangan. Liberty, Yogyakarta (2004)

[5] Rahajaputra, H. : BukuPanduan Praktik Manajemen Keuangan dan Akuntansi untuk Eksekutif Perusahaan. (2009) Retrieved from: http://library.uny.ac.id/sirkulasi/index.php?p=show detail\&id=30532

[6] Syamsuddin, L. : Manajemen Keuangan Perusahaan. PT. Raja Grafindo Persada, Jakarta (2000)

[7] Wiagustini, N.P. : Dasar-Dasar Manajemen Keuangan. Udayana University Press, Denpasar (2010)

[8] Wild, J. J., et al. : Financial Statement Analysis. Salemba Empat, Jakarta (2005) 